\title{
Optical, Electrical and Photocatalytic Properties of the Ternary Semiconductors $\mathrm{Zn}_{x} \mathrm{Cd}_{1-x} \mathrm{~S}, \mathrm{Cu}_{x} \mathrm{Cd}_{1-x} \mathrm{~S}$ and $\mathrm{Cu}_{x} \mathrm{Zn}_{1-x} \mathrm{~S}$
}

\author{
Sandra Andrea Mayén-Hernández, ${ }^{1}$ David Santos-Cruz, ${ }^{1}$ Francisco de Moure-Flores, \\ Sergio Alfonso Pérez-García, ${ }^{2}$ Liliana Licea-Jiménez, ${ }^{2}$ Ma. Concepción Arenas-Arrocena, ${ }^{3}$ \\ José de Jesús Coronel-Hernández, ${ }^{1}$ and José Santos-Cruz ${ }^{1}$ \\ ${ }^{1}$ Facultad de Química, Materiales Universidad Autónoma de Querétaro, 76010 Querétaro, QRO, Mexico \\ ${ }^{2}$ Centro de Investigación en Materiales Avanzados S.C., Alianza Norte 202, 66600 Apodaca, NL, Mexico \\ ${ }^{3}$ Escuela Nacional de Estudios Superiores, Unidad León, UNAM, León 36969, GTO, Mexico \\ Correspondence should be addressed to José Santos-Cruz; jsantos@uaq.edu.mx
}

Received 14 June 2014; Revised 12 July 2014; Accepted 13 July 2014; Published 3 August 2014

Academic Editor: Jiaguo Yu

Copyright (C) 2014 Sandra Andrea Mayén-Hernández et al. This is an open access article distributed under the Creative Commons Attribution License, which permits unrestricted use, distribution, and reproduction in any medium, provided the original work is properly cited.

\begin{abstract}
The effects of vacuum annealing at different temperatures on the optical, electrical and photocatalytic properties of polycrystalline and amorphous thin films of the ternary semiconductor alloys $\mathrm{Zn}_{x} \mathrm{Cd}_{1-x} \mathrm{~S}, \mathrm{Cu}_{x} \mathrm{Cd}_{1-x} \mathrm{~S}$ and $\mathrm{Cu}_{x} \mathrm{Zn}_{1-x} \mathrm{~S}$ were investigated in stacks of binary semiconductors obtained by chemical bath deposition. The electrical properties were measured at room temperature using a four-contact probe in the Van der Pauw configuration. The energy band gap of the films varied from 2.30 to $2.85 \mathrm{eV}$. The photocatalytic activity of the semiconductor thin films was evaluated by the degradation of an aqueous methylene blue solution. The thin film of $\mathrm{Zn}_{x} \mathrm{Cd}_{1-x} \mathrm{~S}$ annealed under vacuum at $300^{\circ} \mathrm{C}$ exhibited the highest photocatalytic activity.
\end{abstract}

\section{Introduction}

Current materials science requires the creation of new, simple, and low-cost ternary and quaternary semiconductor materials with controllable chemical and physical properties. The chalcogenides have received attention for their ability to relatively easily form binary, ternary, and quaternary compounds. The physical and chemical properties of these compounds principally depend on their compositions.

The chalcogenides have many applications, including photodetectors, photovoltaic devices, optical coatings, electro-optic modulators, field-effect transistors, sensors, transducers, light sources and lasers, and photophysical and photocatalytic applications [1-16]. Ternary and quaternary compounds can easily be obtained from solid-state reactions of bilayers of binary chalcogenides because of the unique physical and chemical properties of these species, including the ionic radii of $\mathrm{Cd}^{2+}, \mathrm{Zn}^{2+}, \mathrm{Cu}^{2+}$, and $\mathrm{Cu}^{1+}$, which are $103,83,72$, and $96 \mathrm{pm}$, respectively [17]. Additionally, wide solubility ranges can be expected for zinc and copper ions in
$\mathrm{CdS}$ and $\mathrm{CuS}$ in films of ternary $\mathrm{Zn}_{x} \mathrm{Cd}_{1-x} \mathrm{~S}, \mathrm{Cu}_{x} \mathrm{Cd}_{1-x} \mathrm{~S}$, and $\mathrm{Cu}_{x} \mathrm{Zn}_{1-x} \mathrm{~S}$ compounds. $\mathrm{Zn}$ and $\mathrm{Cu}$ ions can fill substitutional or interstitial sites in the lattices of CdS and CuS [18].

\section{Experimental Methods}

2.1. CdS Thin Films. CdS thin films were grown on Corning glass slides by chemical bath deposition (CBD) at a temperature of $90 \pm 1^{\circ} \mathrm{C}$, over a deposition time of $40 \mathrm{~min}$. The samples were prepared by immersing the substrates vertically in an aqueous solution. The reagents used to prepare the films were cadmium acetate $\left[\mathrm{Cd}\left(\mathrm{CH}_{3} \mathrm{COO}\right)_{2} 2 \mathrm{H}_{2} \mathrm{O}\right]$, ammonium acetate $\left(\mathrm{CH}_{3} \mathrm{COONH}_{4}\right)$, ammonium hydroxide $\left(\mathrm{NH}_{4} \mathrm{OH}\right)$, and thiourea $\left[\left(\mathrm{NH}_{2}\right)_{2} \mathrm{CS}\right]$. Cadmium acetate and thiourea served as the sources of $\mathrm{Cd}$ and $\mathrm{S}$, respectively. The other components formed complexes in the reaction process and maintained a pH of 9 . Highly pure water $(\approx 18 \mathrm{M} \Omega)$ was used in the preparation of all of the solutions. The temperature was maintained at $90 \pm 1^{\circ} \mathrm{C}$ with a hot plate equipped with a magnetic stirrer. After being grown, the thin films were rinsed 
in highly pure water under ultrasonication for $10 \mathrm{~min}$. The average thickness of the films was $80 \pm 10 \mathrm{~nm}$ [19].

2.2. CuS Thin Films. CuS thin films were grown on CdS/Corning glass substrates by the CBD technique at $40 \pm$ $1^{\circ} \mathrm{C}$, over a deposition time of $60 \mathrm{~min}$. The glass slides were immersed vertically in an aqueous solution of copper sulfate $\left(\mathrm{CuSO}_{4} \cdot 5 \mathrm{H}_{2} \mathrm{O}\right)$, sodium acetate $(\mathrm{NaCOOH})$, triethanolamine $\left(\mathrm{HOCH}_{2} \mathrm{CH}_{2}\right)_{3} \mathrm{~N}$, and thiourea $\left(\mathrm{CH}_{4} \mathrm{~N}_{2} \mathrm{~S}\right)$. The $[\mathrm{Cu}] /[\mathrm{S}]$ ratio was 1.5 . Highly pure water $(\approx 18 \mathrm{M} \Omega)$ was used in the solutions. The temperature was controlled with a hot plate equipped with a magnetic stirrer. Copper sulfate and thiourea served as the sources of copper and sulfur, respectively. After being grown, the thin films were rinsed in highly pure water under ultrasonication for $10 \mathrm{~min}$ [20]. The average thickness of the films was $90 \pm 10 \mathrm{~nm}$.

2.3. ZnS Thin Films. ZnS thin films were grown on CdS/Corning glass slides by the CBD technique at a temperature of $70 \pm 1^{\circ} \mathrm{C}$, over a deposition time of $120 \mathrm{~min}$. The samples were prepared by immersing the substrates vertically in the aqueous solution. The reagents used to prepare the films were zinc acetate and thioacetamide. Zinc acetate $\left[\left(\mathrm{CH}_{3} \mathrm{CO}_{2}\right)_{2} \mathrm{Zn}\right]$ and thioacetamide $\left(\mathrm{CH}_{3} \mathrm{CSNH}_{2}\right)$ served as the sources of $\mathrm{Zn}$ and $\mathrm{S}$, respectively. Highly pure water $(\approx 18 \mathrm{M} \Omega)$ was used in the preparation of all of the solutions. The temperature was maintained at $70 \pm 1^{\circ} \mathrm{C}$ with a hot plate equipped with a magnetic stirrer. After being grown, the thin films were rinsed in highly pure water under ultrasonication for $10 \mathrm{~min}$. The average thickness of the films was $75 \pm 10 \mathrm{~nm}$.

Stacked bilayers of $\mathrm{ZnS} / \mathrm{CdS} /$ glass, CuS/ZnS/glass, and $\mathrm{CuS} / \mathrm{CdS} /$ glass were fabricated to obtain ternary compounds. After the growth of the second layer with different thicknesses, they were immediately thermally annealed at different temperatures ranging from 100 to $450^{\circ} \mathrm{C}$ under vacuum.

The ultraviolet-visible (UV-Vis) spectra of the films were measured on a Perkin-Elmer Lambda-2 spectrophotometer with an uncoated glass substrate placed in the reference beam. The atomic concentrations of the various elements composing the films were measured by electron dispersion spectroscopy (EDS) using a Philips XL30-ESEM. XRD measurements were performed with a RIGAKU Ultima IV using $\mathrm{Cu}$ $K \alpha$ radiation $(\lambda=1.54 \AA)$. The films thicknesses were measured on a Sloan Dektak IIA. The resistivity of the films was characterized at ambient temperature using a Loresta-GP instrument.

A photocatalytic activity test was performed with $3.5 \mathrm{~mL}$ of an aqueous solution of methylene blue (MB) at a concentration of $2 \times 10^{-5} \mathrm{~mol} / \mathrm{L}$ and the ternary thin films were placed in a quartz cell with dimensions of $1 \mathrm{~cm} \times 1 \mathrm{~cm} \times$ $4 \mathrm{~cm}$ and irradiated with a commercial germicidal lamp $(\lambda$ $=252 \mathrm{~nm}, 11 \mathrm{~W})$. A rectangular sample with an area of $2 \mathrm{~cm}^{2}$ was inserted into the interior of the quartz cell. The reaction vessel was fixed at a distance of $4.5 \mathrm{~cm}$ from the irradiation lamp. The irradiation times were 1 to $5 \mathrm{~h}$, applied in 1 - $\mathrm{h}$ step. The residual concentration was quantified by UV-Vis absorption spectroscopy at $663 \mathrm{~nm}$. The spectrophotometer was previously calibrated with external calibration standards (2, $1.5,1.0,0.5$, and $\left.0.25 \times 10^{-5} \mathrm{~mol} / \mathrm{L}\right)$.
TABLE 1: Mean compositions in at. \%, determined by EDS of the (vacuum-annealed) ternary semiconductor compounds.

\begin{tabular}{lccc}
\hline Sample & $T_{\text {Ann }} /\left({ }^{\circ} \mathrm{C}\right)$ & $\mathrm{Zn}$ (at. \%) & Compound \\
\hline $\mathrm{Zn}_{x} \mathrm{Cd}_{1-x} \mathrm{~S}$ & 250 & 29.43 & $\mathrm{Zn}_{0.3} \mathrm{Cd}_{0.7} \mathrm{~S}$ \\
& 450 & 44.84 & $\mathrm{Zn}_{0.45} \mathrm{Cd}_{0.55} \mathrm{~S}$ \\
\hline \multirow{4}{*}{$\mathrm{Cu}_{x} \mathrm{Cd}_{1-x} \mathrm{~S}$} & 250 & $\mathrm{Cu}$ (at. \%) & \\
& 450 & 11.24 & $\mathrm{Cu}_{0.11} \mathrm{Cd}_{0.89} \mathrm{~S}$ \\
$\mathrm{Cu}_{x} \mathrm{Zn}_{1-x} \mathrm{~S}$ & 250 & 18.03 & $\mathrm{Cu}_{0.18} \mathrm{Cd}_{0.82} \mathrm{~S}$ \\
& 450 & $\mathrm{Cu}$ (at. \%) & \\
& & 28.59 & $\mathrm{Cu}_{0.29} \mathrm{Zn}_{0.71} \mathrm{~S}$ \\
\hline
\end{tabular}

\section{Results and Discussion}

Figure 1 shows SEM images of the ternary semiconductor compounds $\mathrm{Zn}_{x} \mathrm{Cd}_{1-x} \mathrm{~S}, \mathrm{Cu}_{x} \mathrm{Cd}_{1-x} \mathrm{~S}$, and $\mathrm{Cu}_{x} \mathrm{Zn}_{1-x} \mathrm{~S}$ annealed under vacuum at $250^{\circ} \mathrm{C}$ and $450^{\circ} \mathrm{C}$. All films covered the substrate surface and were free of pinholes. For films of the semiconductor compound $\mathrm{Zn}_{x} \mathrm{Cd}_{1-x} \mathrm{~S}$ annealed at $250^{\circ} \mathrm{C}$, the superficial morphology was composed of agglomerates approximately $160 \mathrm{~nm}$ in diameter with a welldefined spherical shape (Figure 1(a)). The spheres contained small particles measuring $8.5 \mathrm{~nm}$. The spherical shapes of the agglomerates were lost in films annealed at $450^{\circ} \mathrm{C}$ and nanocracks are evident on the surface of these films. The $\mathrm{Cu}_{x} \mathrm{Cd}_{1-x} \mathrm{~S}$ thin films annealed at $250^{\circ} \mathrm{C}$ were composed of irregular agglomerates with approximately circular, asymmetric shapes, and a distribution of sizes and both small particles (Figure 1(c)) and nanocracks were evident. At an annealing temperature of $450^{\circ} \mathrm{C}$, the agglomerates exhibited better-defined shapes and stacking faults (Figure 1(d)). The thin films of the $\mathrm{Zn}_{x} \mathrm{Cu}_{1-x} \mathrm{~S}$ semiconductor demonstrated a superficially amorphous nature (Figures 1(e) and 1(f)).

Table 1 shows the EDS analysis results of the three ternary compounds at the vacuum annealing temperatures of 250 and $450^{\circ} \mathrm{C}$. The compounds containing cadmium are generally rich in cadmium at low temperature $\left(250^{\circ} \mathrm{C}\right)$; however, at high temperature, where diffusion is favored, the cadmium concentration diminishes and, consequently, the respective concentrations of zinc and copper increase $\left(\mathrm{Zn}_{x} \mathrm{Cd}_{1-x} \mathrm{~S}\right.$ and $\left.\mathrm{Cu}_{x} \mathrm{Cd}_{1-x} \mathrm{~S}\right)$. The compound $\mathrm{Cu}_{x} \mathrm{Zn}_{1-x} \mathrm{~S}$ is rich in zinc at low temperature. The copper concentration increases at high temperature.

Figures 2(a) and 2(b) display the XRD results obtained over a $2 \theta$ range of 15 to 60 degrees for the ternary semiconductor alloys $\mathrm{Cu}_{x} \mathrm{Cd}_{1-x} \mathrm{~S}, \mathrm{Cu}_{x} \mathrm{Zn}_{1-x} \mathrm{~S}$, and $\mathrm{Zn}_{x} \mathrm{Cd}_{1-x} \mathrm{~S}$ annealed under vacuum. For Figure 2(a) in all cases, the thin films were amorphous independent of the annealing temperature. At $250^{\circ} \mathrm{C}$, the samples were most amorphous, and at $450^{\circ} \mathrm{C}$, small peaks appeared. Figure $2(\mathrm{a})(\mathrm{A})$ shows the $\mathrm{XRD}$ results obtained for thin films of $\mathrm{Cu}_{x} \mathrm{Cd}_{1-x} \mathrm{~S}$, the patterns show two peaks at $44.28^{\circ}$ and $52.44^{\circ}$ and at $43.04^{\circ}$ and $47.8^{\circ}$ for films annealed under vacuum at $250^{\circ} \mathrm{C}$ and $450^{\circ} \mathrm{C}$, respectively. Figure 2 (a) (B) shows the $\mathrm{XRD}$ results obtained for nanocrystalline thin films of $\mathrm{Cu}_{x} \mathrm{Zn}_{1-x} \mathrm{~S}$, which indicate a single one peak at $43.26^{\circ}$ and $45.16^{\circ}$ for films annealed under 

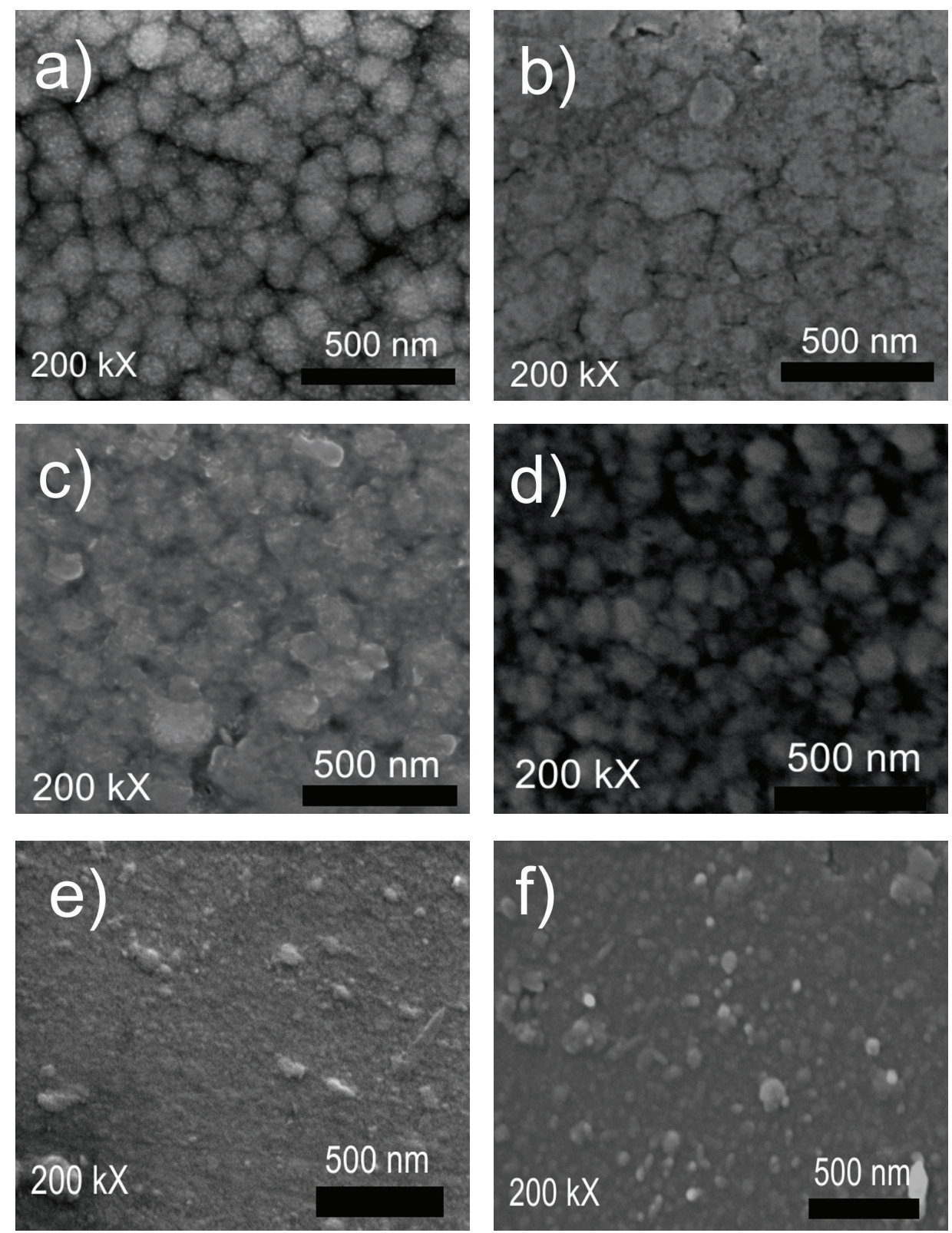

FIGURE 1: SEM images of the chalcogenides studied (a) and (b) $\mathrm{Zn}_{x} \mathrm{Cd}_{1-x} \mathrm{~S}$, (c) and (d) $\mathrm{Cu}_{x} \mathrm{Cd}_{1-x} \mathrm{~S}$, and (e) and (f) $\mathrm{Cu}_{x} \mathrm{Zn}_{1-x} \mathrm{~S}$ annealed at $250^{\circ} \mathrm{C}\left((\mathrm{a}),(\mathrm{c})\right.$, and (e)) and $450^{\circ}((\mathrm{b}),(\mathrm{d})$, and (f)), respectively.

vacuum at $250^{\circ} \mathrm{C}$ and $450^{\circ} \mathrm{C}$, respectively. The small peaks made it difficult to identify the phase.

As shown in Figure 2(b) (A), at $250-450^{\circ} \mathrm{C} \mathrm{Zn}_{x} \mathrm{Cd}_{1-x} \mathrm{~S}$ shows peaks at $25.13^{\circ}, 26.8^{\circ}, 44.2^{\circ}$, and $52.4^{\circ}$, corresponding to the hexagonal wurtzite planes of (100), (002), (110), and (201) in thin films of the standard PDF Card 00-049-1302. Figure 2(b) (B) shows that the orientation of the films is in the plane (002), with the increase of annealing temperature, these peaks move to higher diffraction angle, indicative of an increase of $\mathrm{Zn}$ content in the films. The grains size was calculated from Scherrer's equation for the peaks (002) as a function of the annealing temperature and varied for
$16.316 \mathrm{~nm}, 19.95 \mathrm{~nm}, 19.43 \mathrm{~nm}$, and $19.50 \mathrm{~nm}$, respectively, for $250,300,350$, and $400^{\circ} \mathrm{C}$.

Figures 3(a), 3(b), and 3(c), respectively, show the UVVis transmission spectra as a function of annealing temperature for $\mathrm{Zn}_{x} \mathrm{Cd}_{1-x} \mathrm{~S}, \mathrm{Cu}_{x} \mathrm{Cd}_{1-x} \mathrm{~S}$, and $\mathrm{Cu}_{x} \mathrm{Zn}_{1-x} \mathrm{~S}$ films annealed under vacuum. The $\mathrm{Zn}_{x} \mathrm{Cd}_{1-x} \mathrm{~S}$ films exhibited high transmittances $>80 \%$ over an annealing temperature range of $250^{\circ} \mathrm{C}$ to $450^{\circ} \mathrm{C}$. For the $\mathrm{Cu}_{x} \mathrm{Cd}_{1-x} \mathrm{~S}$ thin films, the transmittance was approximately $65 \%$; higher transmittance was observed for the films annealed under vacuum at $300^{\circ} \mathrm{C}$ than for those annealed at $250^{\circ} \mathrm{C}$. The $\mathrm{Cu}_{x} \mathrm{Zn}_{1-x} \mathrm{~S}$ thin films showed the lowest transmittance values of 35 to $50 \%$; the 


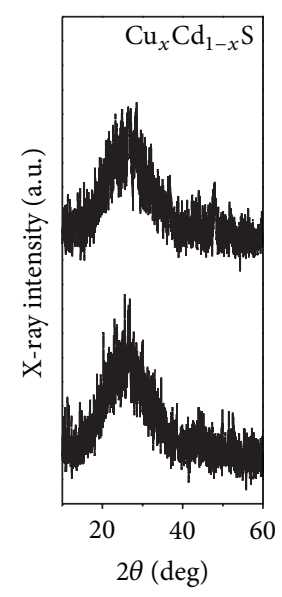

(A)

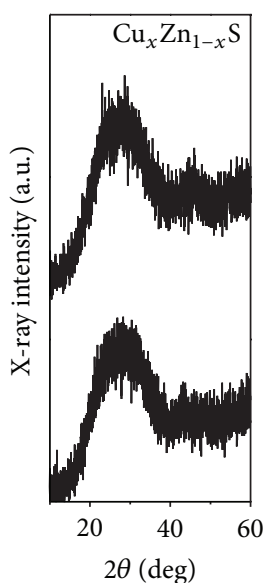

(B)

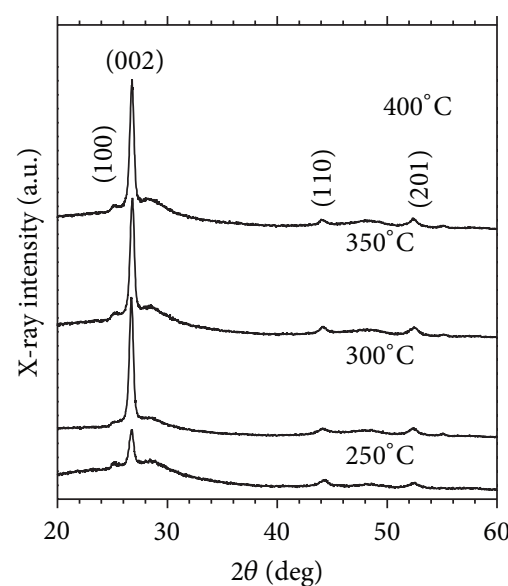

(A)

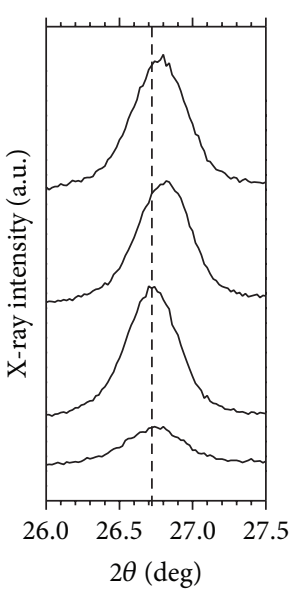

(B)

(a)

(b)

Figure 2: (a) X-ray diffraction patterns of the ternary semiconductor compounds annealed at $250^{\circ} \mathrm{C}$ (bottom patterns) and $450^{\circ} \mathrm{C}$ (top patterns) of (A) $\mathrm{Cu}_{x} \mathrm{Cd}_{1-x} \mathrm{~S}$ and (B) $\mathrm{Cu}_{x} \mathrm{Zn}_{1-x} \mathrm{~S}$. (b) X-ray diffraction patterns of the ternary semiconductor compounds of $\mathrm{Zn}_{x} \mathrm{Cd}{ }_{1-x} \mathrm{~S},(\mathrm{~A})$ as a function of annealing temperature and (B) zoom in of the peaks (002) to observe the shift.

highest transmittance was observed for the films annealed at $350^{\circ} \mathrm{C}$ and the lowest for those annealed at $300^{\circ} \mathrm{C}$. The optical band gap, $E_{g}$, of each film was calculated using the Tauc equation by plotting $(\alpha h \nu)^{2}$ as a function of $h v$, where $\alpha$ is the optical absorption coefficient and $h \nu$ is the photon energy. In the graphs, the linear portion of the curve was extrapolated to $(\alpha h \nu)^{2}=0$. The band gap is shown as a function of the annealing temperature in Figure 4. For $\mathrm{Zn}_{x} \mathrm{Cd}_{1-x} \mathrm{~S}$, the $E_{g}$ values decreased from 2.83 to $2.5 \mathrm{eV}$ as a function of the vacuum annealing temperature. For the $\mathrm{Cu}_{x} \mathrm{Cd}_{1-x} \mathrm{~S}$ thin films, the $E_{g}$ values decreased from 2.43 to $2.28 \mathrm{eV}$ by increasing the annealing temperature. The $\mathrm{Zn}_{x} \mathrm{Cu}_{1-x} \mathrm{~S}$ thin films showed $E_{g}$ values of 2.80 to $2.65 \mathrm{eV}$, with the increase of the annealing temperature. The $E_{g}$ values are in agreement with the values reported by other research groups [21-23]. In general, the band gap decreases as the annealing temperature increases; this effect may be caused by both the greater diffusion between the bilayers and the formation of the ternary alloy.

Figure 5 shows the resistivity values of the ternary semiconductor compounds. The thin films of $\mathrm{Zn}_{x} \mathrm{Cd}_{1-x} \mathrm{~S}$ were highly resistive independent of thermal annealing; the resistivity values were greater than $10^{6} \Omega \cdot \mathrm{cm}$ (results not shown). Figure 5 displays the resistivity values of the $\mathrm{Cu}_{x} \mathrm{Cd}_{1-x} \mathrm{~S}$ and $\mathrm{Cu}_{x} \mathrm{Zn}_{1-x} \mathrm{~S}$ films annealed under vacuum as a function of the annealing temperature. The values for $\mathrm{Cu}_{x} \mathrm{Cd}_{1-x} \mathrm{~S}$ decreased as the annealing temperature increased. The minimum resistivity occurred at $300^{\circ} \mathrm{C}\left(2.74 \times 10^{-3} \Omega \cdot \mathrm{cm}\right)$, above this temperature, the resistivity value increased. The resistivity values for the $\mathrm{Cu}_{x} \mathrm{Zn}_{1-x} \mathrm{~S}$ samples decreased as the annealing temperature increased. The lowest value was obtained at $350^{\circ} \mathrm{C}$ $\left(4.11 \times 10^{-4} \Omega \cdot \mathrm{cm}\right)$ and, for temperatures above $350^{\circ} \mathrm{C}$, the resistivity values increased.

The change of resistivity values with the change of the annealing temperatures could be attributed to the diffusion of copper ions on the matrix of $\mathrm{CdS}$ and $\mathrm{ZnS}$, with the temperature increase and the presence of nanocracks on the surface of the films at elevated temperatures. The ionic radii of $\mathrm{Cd}^{2+}, \mathrm{Zn}^{2+}$, and $\mathrm{Cu}^{2+}$, are 103,83 , and $72 \mathrm{pm}$, respectively [17], on the other hand, the copper ions could be introduced more effectively with the increase of the temperature until the saturation, and possibly the segregation phenomena takes place at different temperatures $\left(300\right.$ and $350^{\circ} \mathrm{C}$ for $\mathrm{Cu}_{x} \mathrm{Cd}_{1-x} \mathrm{~S}$ and $\mathrm{Cu}_{x} \mathrm{Zn}_{1-x} \mathrm{~S}$, resp.). Copper ions are closer to the ionic radii of $\mathrm{Zn}^{2+}$ than $\mathrm{Cd}^{2+}$. Additionally, copper ions could be introduced more easily in the $\mathrm{ZnS}$ lattice occupied substitutional or interstitial sites in the lattices of $\mathrm{ZnS}$ than in $\mathrm{CdS}$ [18].

To demonstrate the prospective photocatalytic applications of the fabricated materials, the thin films were used as catalysts in the degradation of methylene blue (MB) under germicidal irradiation $(\lambda=252 \mathrm{~nm})$ at room temperature. Figure 6 displays the normalized concentration of $\mathrm{MB}$ in aqueous solution as a function of the vacuum annealing temperature for the three different semiconductor alloys. The concentration was quantified based on the absorption at $653 \mathrm{~nm}$

The absorption is time-dependent, initially, the irradiation time was held constant at $3 \mathrm{~h}$ for all samples. The ternary semiconductor samples generally showed photocatalytic behavior. The sample with the best photobleaching performance was $\mathrm{Zn}_{x} \mathrm{Cd}_{1-x} \mathrm{~S}$ annealed at $300^{\circ} \mathrm{C}$ (see Figure 6).

As indicated in Figure 6, the best samples were $\mathrm{Zn}_{x} \mathrm{Cd}_{1-x} \mathrm{~S}$ and $\mathrm{Cu}_{x} \mathrm{Cd}_{1-x} \mathrm{~S}$ annealed at $300^{\circ} \mathrm{C}$ and $250^{\circ} \mathrm{C}$, respectively. The temporal dependence of the photobleaching of MB by these samples was analyzed. Figure 7(a) shows the normalized $\mathrm{MB}$ concentration as a function of time in hours. The $\mathrm{Zn}_{x} \mathrm{Cd}_{1-x} \mathrm{~S}$ film demonstrated that it is an excellent candidate for photocatalytic applications. In $5 \mathrm{~h}$, the mineralization of $\mathrm{MB}$ was nearly complete $(82 \%)$ for the thin 


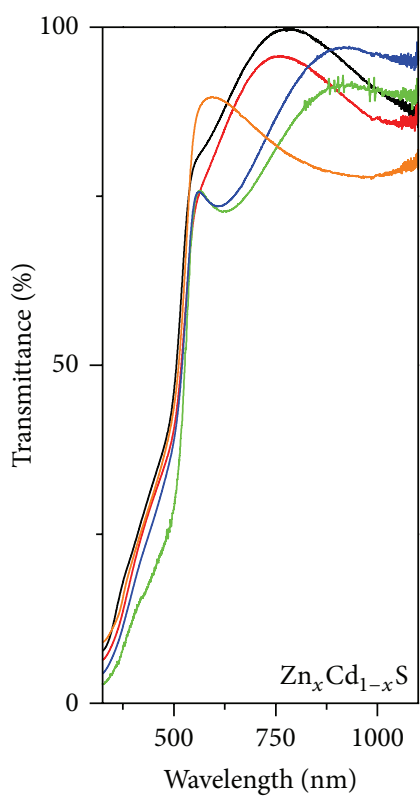

(a)

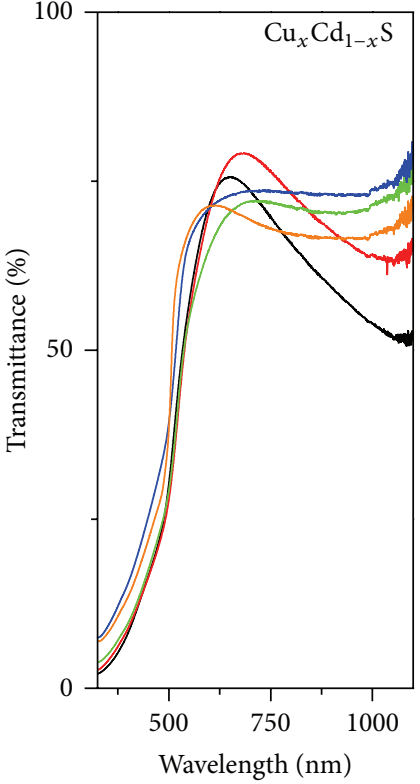

(b)

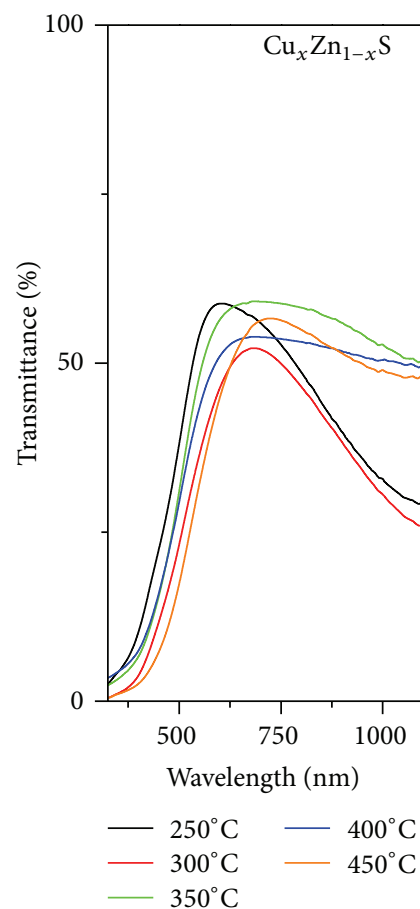

(c)

Figure 3: Optical transmittance spectra of the ternary semiconductor compounds studied.

films of $\mathrm{Zn}_{x} \mathrm{Cd}_{1-x} \mathrm{~S}$ annealed under vacuum at $300^{\circ} \mathrm{C}$. This can be attributed to the synergistic effect of thermal annealing, better crystallinity, and concentration of the $\mathrm{Zn}$ mole fraction to 0.3 and 0.33 for 250 and $300^{\circ} \mathrm{C}$, respectively; similar results were found by an optimal $\mathrm{Zn}$ incorporation corresponding to $x$ approximately $0.2-0.33$ [24-27]. Additionally these results are comparable to the photocatalytic activities reported in the literature for thin films of other materials, such as $\mathrm{ZnO}$ and $\mathrm{TiO}_{2}$, which have been shown to be excellent catalyzers [28-31].

The thin films of $\mathrm{Zn}_{x} \mathrm{Cd}_{1-x} \mathrm{~S}$ were obtained by chemical bath deposition and were annealed under vacuum at $300^{\circ} \mathrm{C}$. Obtaining this film is very economical compared to the preparation of films of $\mathrm{ZnO}$ (sol-gel, sputtering at $T \geq 500^{\circ} \mathrm{C}$ ) and $\mathrm{TiO}_{2}$ (sol-gel, sputtering at $T \geq 450^{\circ} \mathrm{C}$ ). Additionally, our films have high transmittances $(\geq 85 \%)$ and band gaps (2.5 to 


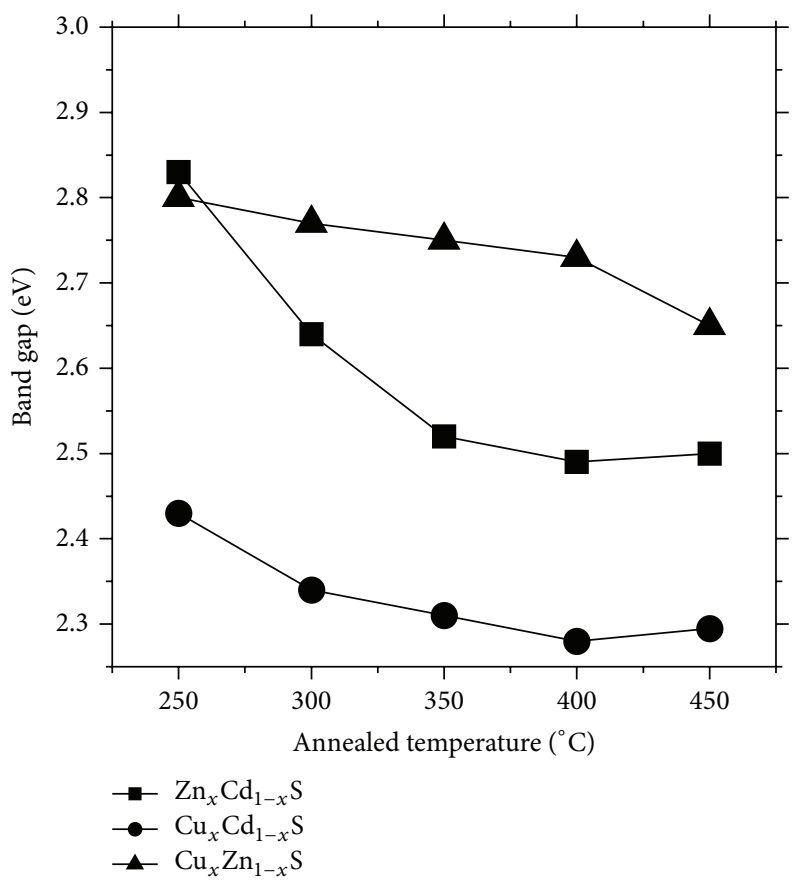

FIgURE 4: Band gap results as a function of the annealing temperature.

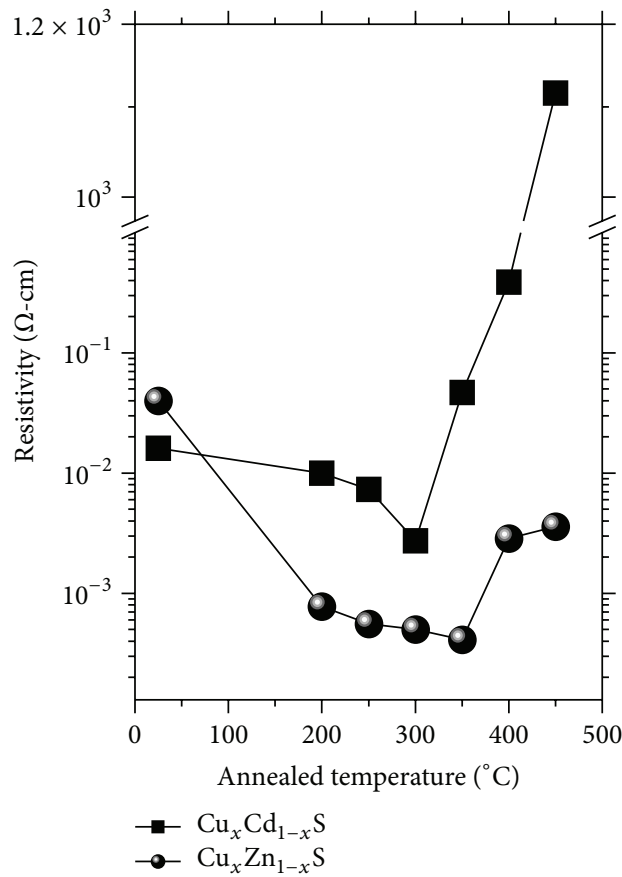

FIGURE 5: Resistivity values as a function of the annealing temperature.

$2.83 \mathrm{eV}$ ) closer to the absorption spectrum of visible light than gaps larger than $3.2 \mathrm{eV}\left(\mathrm{ZnO}\right.$ and $\left.\mathrm{TiO}_{2}\right)$.

For $\mathrm{Cu}_{x} \mathrm{Cd}_{1-x} \mathrm{~S}$ annealed at $250^{\circ} \mathrm{C}$, the extent of mineralization after $5 \mathrm{~h}$ was approximately $50 \%$. Figure 7 (b) displays the absorption spectra of an aqueous solution of $M B$ at different intervals in the presence of a sample of $\mathrm{Zn}_{x} \mathrm{Cd}_{1-x} \mathrm{~S}$

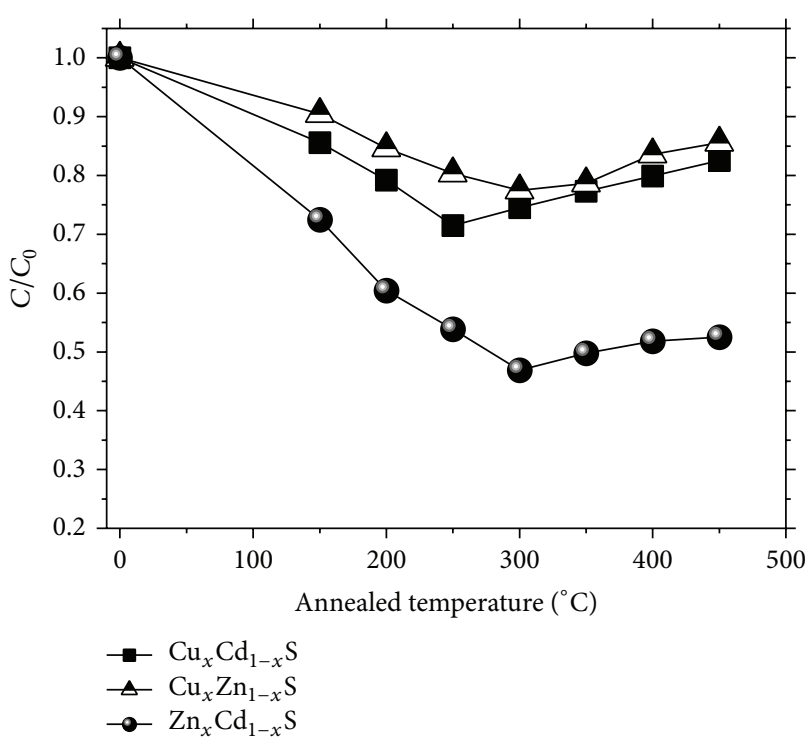

FIGURE 6: Photobleaching of the normalized concentration of MB after $3 \mathrm{~h}$ as a function of the annealing temperature.

annealed at $300^{\circ} \mathrm{C}$. The concentration was quantified based on the absorption at $653 \mathrm{~nm}$. The absorption was timedependent and the complete mineralization of $\mathrm{MB}$ was nearly reached after $5 \mathrm{~h}$ under the experimental conditions described above.

\section{Conclusions}

Simple and economical syntheses of ternary semiconductor alloys of $\mathrm{Zn}_{x} \mathrm{Cd}_{1-x} \mathrm{~S}, \mathrm{Cu}_{x} \mathrm{Cd}_{1-x} \mathrm{~S}$, and $\mathrm{Cu}_{x} \mathrm{Zn}_{1-x} \mathrm{~S}$ were 


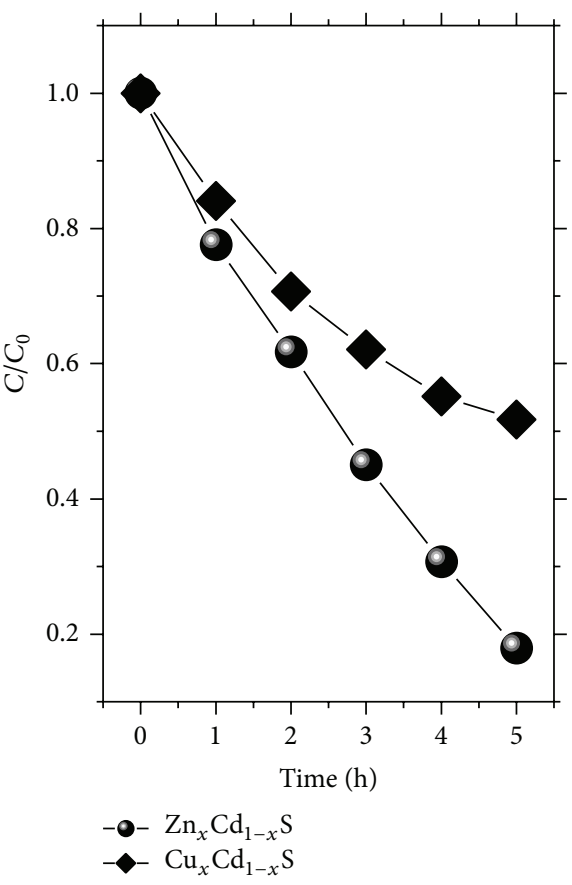

(a)

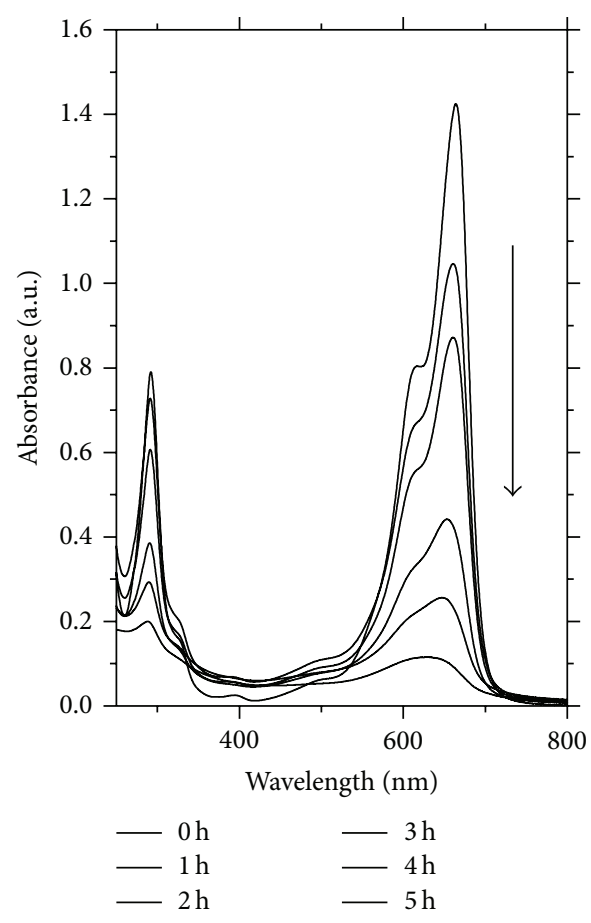

(b)

Figure 7: (a) Photobleaching of the normalized concentration of MB as a function of time for $\mathrm{Zn}_{x} \mathrm{Cd}_{1-x} \mathrm{~S}$ and $\mathrm{Cu}_{x} \mathrm{Cd}_{1-x} \mathrm{~S}$. (b) Absorption spectra of the $\mathrm{Zn}_{x} \mathrm{Cd}_{1-x} \mathrm{~S}$ thin films.

obtained by the chemical bath deposition and subsequent annealing of stacked bilayers of binary semiconductor films. The three compounds showed good optical properties, superficial morphology, and photocatalytic activity. The band gap of the $\mathrm{Cu}_{x} \mathrm{Cd}_{1-x} \mathrm{~S}$ and $\mathrm{Cu}_{x} \mathrm{Zn}_{1-x} \mathrm{~S}$ samples was tuned from 2.3 to $2.85 \mathrm{eV}$. These samples demonstrated the lowest resistivity values of $2.74 \times 10^{-3}$ and $4.11 \times 10^{-4} \Omega \cdot \mathrm{cm}$, respectively, among all of the films that were fabricated. Extensive photodegradation of methylene blue was observed for the $\mathrm{Zn}_{x} \mathrm{Cd}_{1-x} \mathrm{~S}$ film annealed at $300^{\circ} \mathrm{C}$ in vacuum; this activity is comparable to that reported in the literature for thin films of $\mathrm{ZnO}$ and $\mathrm{TiO}_{2}$.

\section{Conflict of Interests}

The authors declare that there is no conflict of interests regarding the publication of this paper.

\section{Acknowledgments}

The authors thank the Universidad Autónoma de Querétaro México for the financial support of this work through the Project FOFI 2012 and the CONACYT Projects CB154787 and CB176450.

\section{References}

[1] K. T. R. Reddy and P. J. Reddy, "Studies of $\mathrm{Zn}_{x} \mathrm{Cd}_{1-x} \mathrm{~S}$ films and $\mathrm{Zn}_{x} \mathrm{Cd}_{1-x} \mathrm{~S} / \mathrm{CuGaSe}_{2}$ heterojunction solar cells," Journal of Physics D: Applied Physics, vol. 25, no. 9, pp. 1345-1348, 1992.
[2] R. N. Bhattacharya, M. A. Contreras, B. Egaas, R. N. Noufi, A. Kanevce, and J. R. Sites, "High efficiency thin-film $\mathrm{CuIn}_{1-x} \mathrm{Ga}_{x} \mathrm{Se}_{2}$ photovoltaic cells using a $\mathrm{Cd}_{1-x} \mathrm{Zn}_{x} \mathrm{~S}$ buffer layer," Applied Physics Letters, vol. 89, no. 25, Article ID 253503, 2006.

[3] I. O. Oladeji, L. Chow, C. S. Ferekides, V. Viswanathan, and Z. Zhao, "Metal/CdTe/CdS/Zn ${ }_{x} \mathrm{Cd}_{1-x}$ S/TCO/glass: a new CdTe thin film solar cell structure," Solar Energy Materials Solar Cells, vol. 61, no. 2, pp. 203-211, 2000.

[4] I. O. Oladeji and L. Chow, "Synthesis and processing of CdS/ZnS multilayer films for solar cell application," Thin Solid Films, vol. 474, no. 1-2, pp. 77-83, 2005.

[5] R. Nagarajan, "Nanoparticles: building blocks for nanotechnology," in Nanoparticles: Synthesis, Stabilization, Passivation, and Functionalization, vol. 996 of ACS Symposium Series, chapter 1, pp. 2-14, American Chemical Society, 2008.

[6] T. L. Chu, S. S. Chu, J. Britt, C. Ferekides, and C. Q. Wu, "Cadmium zinc sulfide films and heterojunctions," Journal of Applied Physics, vol. 70, no. 5, pp. 2688-2693, 1991.

[7] B. Kumar, P. Vasekar, S. A. Pethe, N. G. Dhere, and G. T. Koishiyev, " $\mathrm{Zn}_{x} \mathrm{Cd}_{1-x}$ as a heterojunction partner for $\mathrm{CuIn}_{1-x} \mathrm{Ga}_{x} \mathrm{~S}_{2}$ thin film solar cells," Thin Solid Films, vol. 517, no. 7, pp. 2295-2299, 2009.

[8] C. Jin, W. Zhong, X. Zhang, Y. Deng, C. Au, and Y. Du, "Synthesis and wavelength-tunable luminescence property of wurtzite Zn xCd1-xS nstructures," Crystal Growth and Design, vol. 9, no. 11, pp. 4602-4606, 2009.

[9] F. Benkabou, H. Aourag, and M. Certier, "Atomistic study of zinc-blende CdS, CdSe, $\mathrm{ZnS}$, and $\mathrm{ZnSe}$ from molecular dynamics," Materials Chemistry and Physics, vol. 66, no. 1, pp. $10-16,2000$. 
[10] H. E. Ruda, Wide-Gap II-VI Compounds for Opto-Electronic Applications, Springer, 1992.

[11] T. P. Kumar, S. Saravanakumar, and K. Sankaranarayanan, "Effect of annealing on the surface and band gap alignment of CdZnS thin films," Applied Surface Science, vol. 257, no. 6, pp. 1923-1927, 2011.

[12] N. A. Noor, N. Ikram, S. Ali, S. Nazir, S. M. Alay-E-Abbas, and A. Shaukat, "First-principles calculations of structural, electronic and optical properties of $\mathrm{Cd}_{x} \mathrm{Zn}_{1-x} \mathrm{~S}$ alloys," Journal of Alloys and Compounds, vol. 507, no. 2, pp. 356-363, 2010.

[13] M. Nyman, K. Jenkins, M. J. Hampden-Smith et al., "FeedRate-Limited Aerosol-Assisted Chemical Vapor deposition of $\mathrm{Cd}_{x} \mathrm{Zn}_{1-x} \mathrm{~S}$ and $\mathrm{ZnS}: \mathrm{Mn}$ with Composition Control," Chemistry of Materials, vol. 10, no. 3, pp. 914-921, 1998.

[14] P. Chen, J. E. Nicholls, M. O’Neill et al., "Spectroscopic evidence for different laser gain mechanisms in optically pumped ZnCdS/ZnS quantum well structures," Journal of Applied Physics, vol. 84, no. 10, pp. 5621-5625, 1998.

[15] S. A. Al Kuhaimi and Z. Tulbah, "Structural, compositional, optical, and electrical properties of solution-grown $\mathrm{Zn}_{x} \mathrm{Cd}_{1-x} \mathrm{~S}$ films," Journal of the Electrochemical Society, vol. 147, no. 1, pp. 214-218, 2000.

[16] H. Liu and Y. Zhu, "Synthesis and characterization of ternary chalcogenide ZnCdS $1 \mathrm{D}$ nanostructures," Materials Letters, vol. 62, no. 2, pp. 255-257, 2008.

[17] R. Chang, Chemistry, McGraw Hill, 9th edition, 2007.

[18] A. A. Ziabari and F. E. Ghodsi, "Influence of $\mathrm{Cu}$ doping and post-heat treatment on the microstructure, optical properties and photoluminescence features of sol-gel derived nanostructured CdS thin films," Journal of Luminescence, vol. 141, pp. 121129, 2013.

[19] J. S. Cruz, R. C. Pérez, G. T. Delgado, and O. Z. Angel, “CdS thin films doped with metal-organic salts using chemical bath deposition," Thin Solid Films, vol. 518, no. 7, pp. 1791-1795, 2010.

[20] J. Santos Cruz, S. A. Mayén Hernández, R. Mejía Rodríguez, R. Castanedo Pérez, G. Torres Delgado, and S. Jiménez Sandoval, "Effect of the sintering temperature on the photocatalytic activity of CdO+ CdTiO 3 thin films," Chalcogenide Letters, vol. 9, no. 2, pp. 85-91, 2012.

[21] M. A. Mahdi, J. J. Hassan, Z. Hassan, and S. S. Ng, "Growth and characterization of $\mathrm{Zn}_{x} \mathrm{Cd}_{1-x} \mathrm{~S}$ nanoflowers by microwaveassisted chemical bath deposition," Journal of Alloys and Compounds, vol. 541, pp. 227-233, 2012.

[22] M. Adelifard, H. Eshghi, and M. M. B. Mohagheghi, "Synthesis and characterization of nanostructural CuS-ZnS binary compound thin films prepared by spray pyrolysis," Optics Communications, vol. 285, no. 21-22, pp. 4400-4404, 2012.

[23] A. Abdolahzadeh Ziabari and F. E. Ghodsi, "Effects of the $\mathrm{Cd}: \mathrm{Zn}: \mathrm{S}$ molar ratio and heat treatment on the optical and photoluminescence properties of nanocrystalline CdZnS thin films," Materials Science in Semiconductor Processing, vol. 16, no. 6, pp. 1629-1636, 2013.

[24] X. Xu, R. Lu, X. Zhao, Y. Zhu, S. Xu, and F. Zhang, "Novel mesoporous $\mathrm{Zn}_{X} \mathrm{Cd}_{1-X} \mathrm{~S}$ nanoparticles as highly efficient photocatalysts," Applied Catalysis B: Environmental, vol. 125, pp. 1120, 2012.

[25] J. Ran, J. Yu, and M. Jaroniec, " $\mathrm{Ni}(\mathrm{OH})_{2}$ modified CdS nanorods for highly efficient visible-light-driven photocatalytic $\mathrm{H}_{2}$ generation," Green Chemistry, vol. 13, no. 10, pp. 2708-2713, 2011.
[26] J. Zhang, L. F. Qi, J. R. Ran, J. G. Yu, and S. Z. Qiao, "Ternary NiS/ $\mathrm{Zn}_{X} \mathrm{Cd}_{1-X} \mathrm{~S} /$ reduced graphene oxide nanocomposite for enhanced solar photocatalytic $\mathrm{H}_{2}$-production activity," Advanced Energy Materials, 2014.

[27] J. R. Ran, J. Zhang, J. G. Yu, M. Jaroniec, and S. Z. Qiao, "Earthabundant cocatalysts for semiconductor-based photocatalytic water splitting," Chemical Society Reviews, 2014.

[28] G. Torres Delgado, C. I. Zúñiga Romero, S. A. Mayén Hernández, R. Castanedo Pérez, and O. Zelaya Angel, "Optical and structural properties of the sol-gel-prepared $\mathrm{ZnO}$ thin films and their effect on the photocatalytic activity," Solar Energy Materials \& Solar Cells, vol. 93, no. 1, pp. 55-59, 2009.

[29] A. Enesca, L. Isac, and A. Duta, "Hybrid structure comprised of $\mathrm{SnO}_{2}, \mathrm{ZnO}$ and $\mathrm{Cu}_{2} \mathrm{~S}$ thin film semiconductors with controlled optoelectric and photocatalytic properties," Thin Solid Films, vol. 542, pp. 31-37, 2013.

[30] R. A. Carcel, L. Andronic, and A. Duta, "Photocatalytic activity and stability of $\mathrm{TiO}_{2}$ and $\mathrm{WO}_{3}$ thin films," Materials Characterization, vol. 70, pp. 68-73, 2012.

[31] H. Yu and C. Wang, "Photocatalysis and characterization of the gel-derived $\mathrm{TiO}_{2}$ and $\mathrm{P}^{-\mathrm{TiO}_{2}}$ transparent thin films," Thin Solid Films, vol. 519, no. 19, pp. 6453-6458, 2011. 

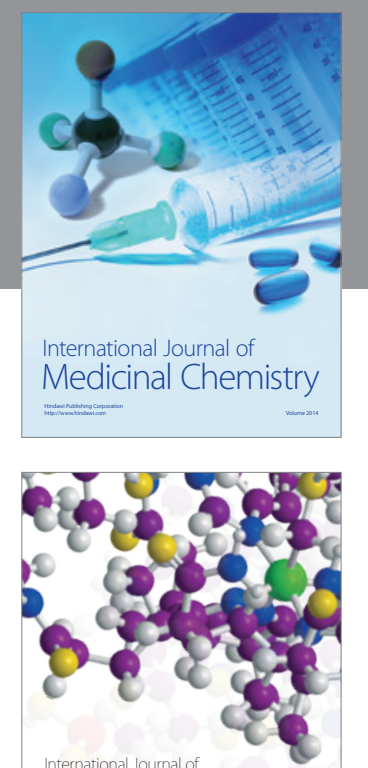

\section{Carbohydrate} Chemistry

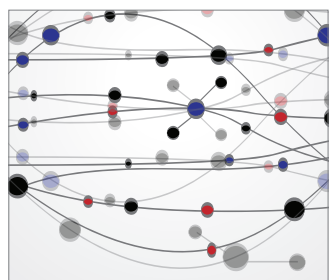

The Scientific World Journal
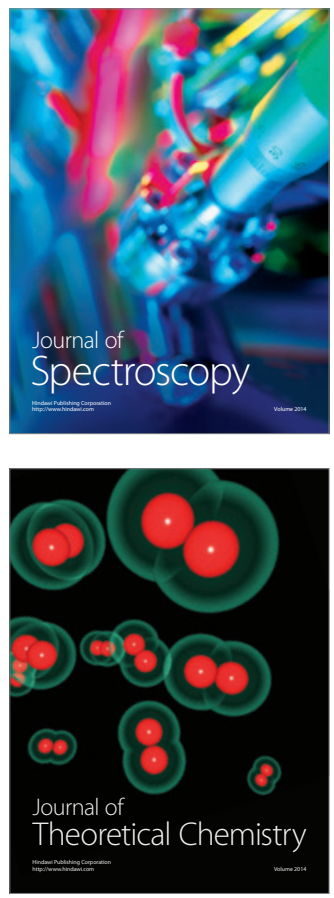
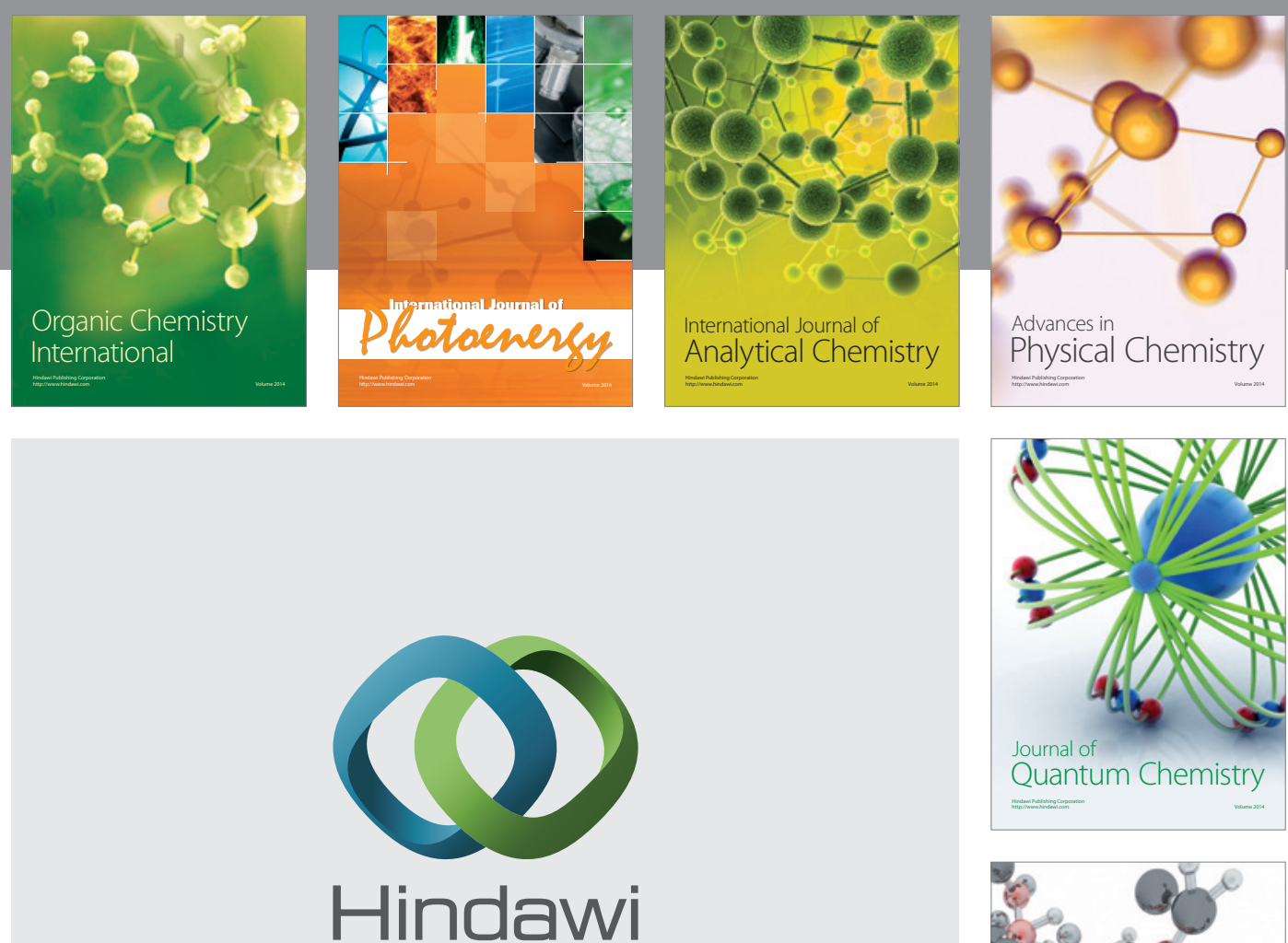

Submit your manuscripts at

http://www.hindawi.com

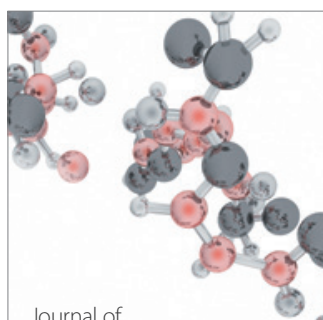

Analytical Methods

in Chemistry

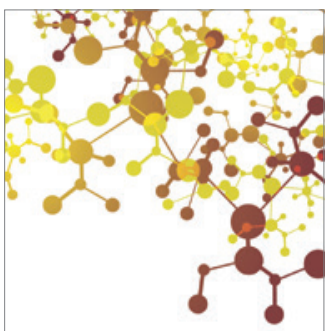

Journal of

Applied Chemistry

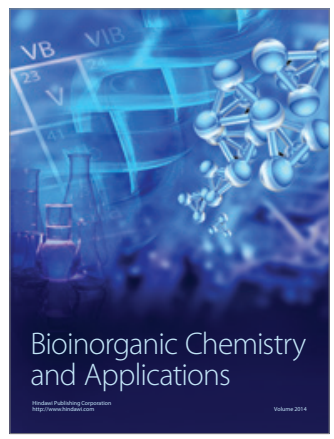

Inorganic Chemistry
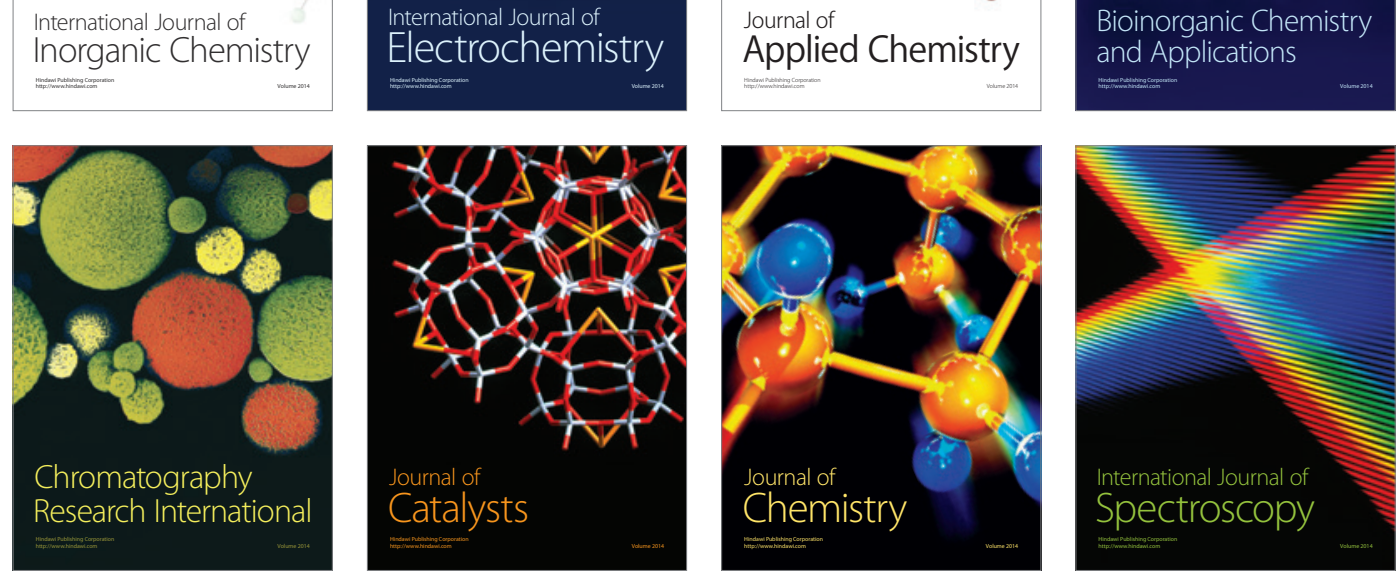